\title{
Analysis of Students Errors in Mathematical Reasoning on Geometry by Gender
}

\author{
Agus Setiawan $^{\mathrm{b}}$, Cholis Sa'dijah ${ }^{\mathrm{a}, *}$ \\ ${ }^{a}$ Universitas Negeri Malang \\ Jalan Semarang No. 5 Malang, 65145, East Java, Indonesia \\ ${ }^{b}$ Institut Agama Islam Ma'arif NU Metro Lampung \\ Jalan RA Kartini No. 28 Metro, 34114, Lampung, Indonesia \\ *E-mail: cholis.sadijah.fmipa@um.ac.id
}

\begin{abstract}
The purpose of this study is to identify the reasoning male and female in solving geometry problems. Using qualitative descriptive approach, the subjects in this study were 42 male and 42 female students from two schools in the district Mesuji Lampung, Indonesia. The instrument used was a test essay consists of two problems related to geometry. The findings of this study indicate that male students have superior reasoning ability than female students. Another finding that students can make mistakes in every stage of reasoning is based on five indicators of reasoning primarily on third indicator it is perform mathematical manipulations and provide a reason or evidence to the truth of the solution, fourth indicator it is checking the validity of an argument, and fifth indicator it is draw conclusions and the first indicator and the second indicator students make a little mistake.
\end{abstract}

\section{Introduction}

Reasoning ability is an important ability in learning mathematics [1]. One of the important goals in mathematics is to teach students on the reasoning [2]. Students often use analogy reasoning methods to solve problems [3]. Mathematical reasoning refers to the ability to analyze mathematical situations and build logical arguments [4]. This is a habit of the mind that can be developed through mathematical applications in different contexts. Students' reasoning abilities must be honed in order students can use logical reasoning to solve a problem math [5]. The development of mathematical reasoning in small group learning activities must be structured to maximize opportunities for each student to be involved in asking questions, elaboration, and other 
verbal communication where students can express their ideas and group members can give feedback [6].

The results showed that reasoning ability had an effect on the success of student achievement in mathematics [7, 8]. In fact, some research states that there is a relationship between mathematical reasoning abilities and achievement in mathematics [9, 10, 11]. Mathematical reasoning abilities can reliably predict student achievement in mathematics [11]. Likewise, the results of their study in Malaysia found the ability of geometry (the ability to reason and spatial ability) is a good predictor of student achievement in mathematics [9].

Meanwhile, several studies show that among students who use statistical strategies, women produce emotional reactions that are significantly stronger than men and recognize the valence of negative images faster than men [12]. Female students outperform male students in languages, male students excel in science and reasoning [13] and gender influences students' mathematical understanding [14].

The results showed that students had difficulty observing regularity, patterns and formulation of generalizations [15]. Students can make mistakes at every stage of structuring, mapping, applying, or verifying. But, mistakes can occur also in the combination of analogical reasoning components, such as the application of structuring [16].

The purpose of this study was to identify the reasoning boys and girls in the wake of the flat side space based component indicators that researchers propose reasoning as in Table 1 below. Table. 1.

Mathematical Reasoning Ability Indicators

\begin{tabular}{|c|c|c|}
\hline $\begin{array}{l}\text { Hendriana, Rohaeti and } \\
\text { Sumarmo [21] }\end{array}$ & Content Standards Dikdasmen [22] & Researcher \\
\hline $\begin{array}{l}\text { 1. Make analogies and generalisi } \\
\text { 2. Provide an explanation by } \\
\text { using models } \\
\text { 3. Use patterns and relationships } \\
\text { to analyze mathematical } \\
\text { situations } \\
\text { 4. Develop and test conjectures } \\
\text { 5. Checking the validity of the } \\
\text { argument } \\
\text { 6. Develop proof } \\
\text { 7. Following the rules enferensi } \\
\text { 8. Draw a conclusion }\end{array}$ & $\begin{array}{l}\text { 1. Presents a mathematical expression } \\
\text { through writing, drawing, sketch or } \\
\text { diagram, } \\
\text { 2. Asking allegations, } \\
\text { 3. Perform mathematical manipulations, } \\
\text { 4. Compile evidence, reasoning or } \\
\text { evidence of the truth of the solution, } \\
\text { 5. Drawing conclusions from the } \\
\text { statement, } \\
\text { 6. Checking the validity of the statement, } \\
\text { and } \\
\text { 7. Finding the pattern or nature of the } \\
\text { symptoms mathematical generalization. }\end{array}$ & $\begin{array}{l}\text { 1. Presents a mathematical } \\
\text { expression through writing, } \\
\text { drawing, sketch or diagram. } \\
\text { 2. Asking conjecture } \\
\text { (conjecture). } \\
\text { 3. Perform mathematical } \\
\text { manipulations and give } \\
\text { reasons or evidence of the } \\
\text { truth of the solution. } \\
\text { 4. Checking the validity of an } \\
\text { argument. } \\
\text { 5. Draw a conclusion. }\end{array}$ \\
\hline
\end{tabular}

\section{Method}

The research uses qualitative descriptive approach. The subjects were students of class VIII junior high school. They have been receiving lessons on the geometry. Overall, subjects totaling 
84 students consisting of 42 male students and 42 female students from two schools in the district Mesuji Lampung, Indonesia.

The research instrument is a problem of geometrical reasoning on cube, cuboids and pyramid. Problem given amounted to two problems. The first problem is "Andi will make a pyramid with a flat rib length of $10 \mathrm{~cm}$ and pyramid height of $12 \mathrm{~cm}$. If the shape of the base of the pyramid is in accordance with the shape of the base on the cube, how much cardboard is needed to make the pyramid?. The second problem is "A bathtub in the form of a cuboid measuring $2 \mathrm{~m} \times 2 \mathrm{~m} \times 3 \mathrm{~m}$ and filled with water. Water in the tub will be flowed through the faucet and held by a number of buckets. The volume of water in a number of buckets is recorded, and the results are as follows:

\begin{tabular}{ll}
\hline Volume of water in a number of buckets & Time required \\
\hline $1 \mathrm{~m}^{2}$ & 10 minute \\
$2 \mathrm{~m}^{2}$ & 20 minute \\
$3 \mathrm{~m}^{2}$ & 30 minute \\
$4 \mathrm{~m}^{2}$ & 40 minute \\
\hline
\end{tabular}

How do you suppose it will take to drain all the water from the tub?

Data collection procedures by asking the subjects to work on any given issue. First, the subject of working on issues related to geometry. Furthermore, the answer sheets were taken and collected by the students. Second, classifying the results of the students' answers were right or wrong according to gender. Third, classify the indicators which students make a mistake in mathematical reasoning. Furthermore, the results were analyzed qualitatively.

\section{Result}

Based on results of data analysis has been done of the two schools, there are $47(55.95 \%)$ students who answer the question correctly with the details of 18 male students and 29 female students and there were $37(44.05 \%)$ students answered incorrectly with the details 24 male students and 13 female students (Figure. 1). Of the two problems are given, the most common mistake is on the first issue than the second issue. 


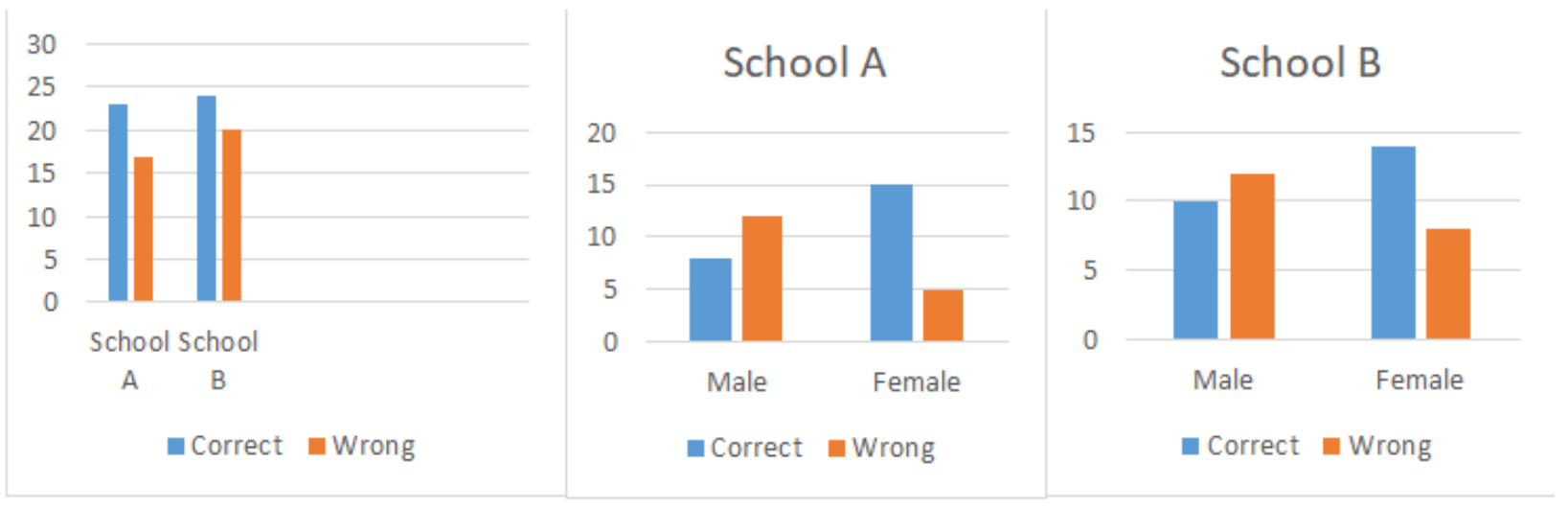

Figure 1. Data of students who answered correctly and incorrectly

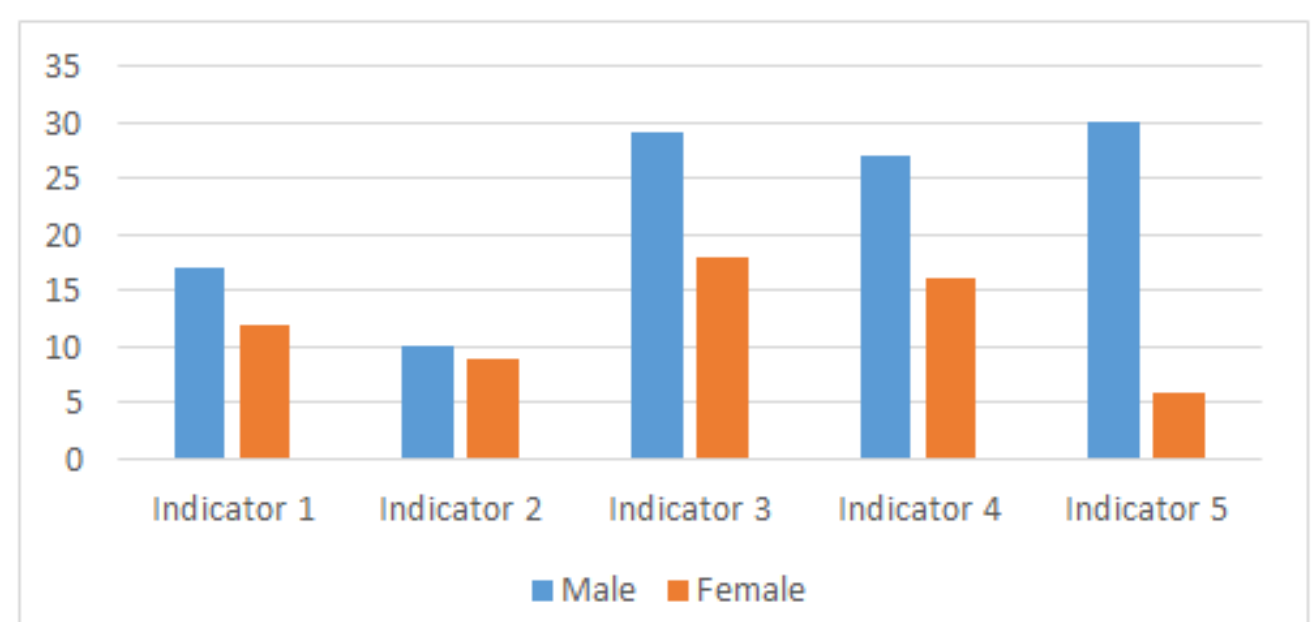

Figure 2. Errors reasoning abilities of students based on indicators

Based on Figure 2, the error often appears on each component of the indicator reasoning. Male students often make mistakes on indicators $3^{\text {rd }}, 4^{\text {th }}$ and $5^{\text {th }}$ ie mathematical manipulation, check the validity of arguments and draw conclusions while the female students in the 3rd and 4th indicator is a mathematical manipulation, check the validity of the argument. Based on that most students often make the mistake of reasoning on indicators $3^{\text {rd }}, 4^{\text {th }}$ and $5^{\text {th }}$ ie mathematical manipulation, check the validity of arguments and draw conclusions.

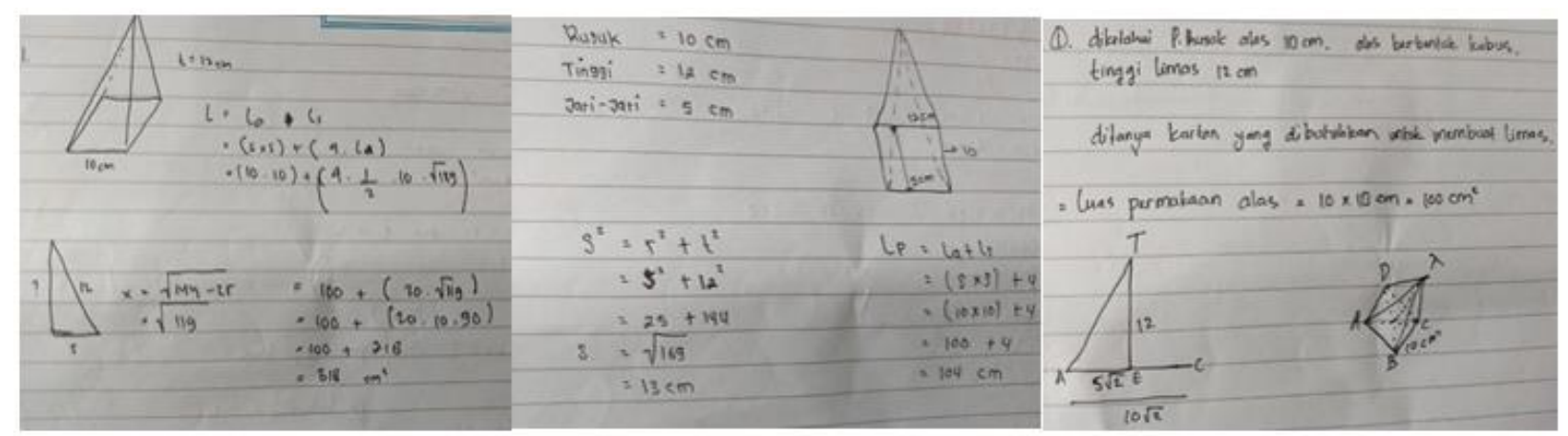

Figure. 3. Error students on issues 1. 


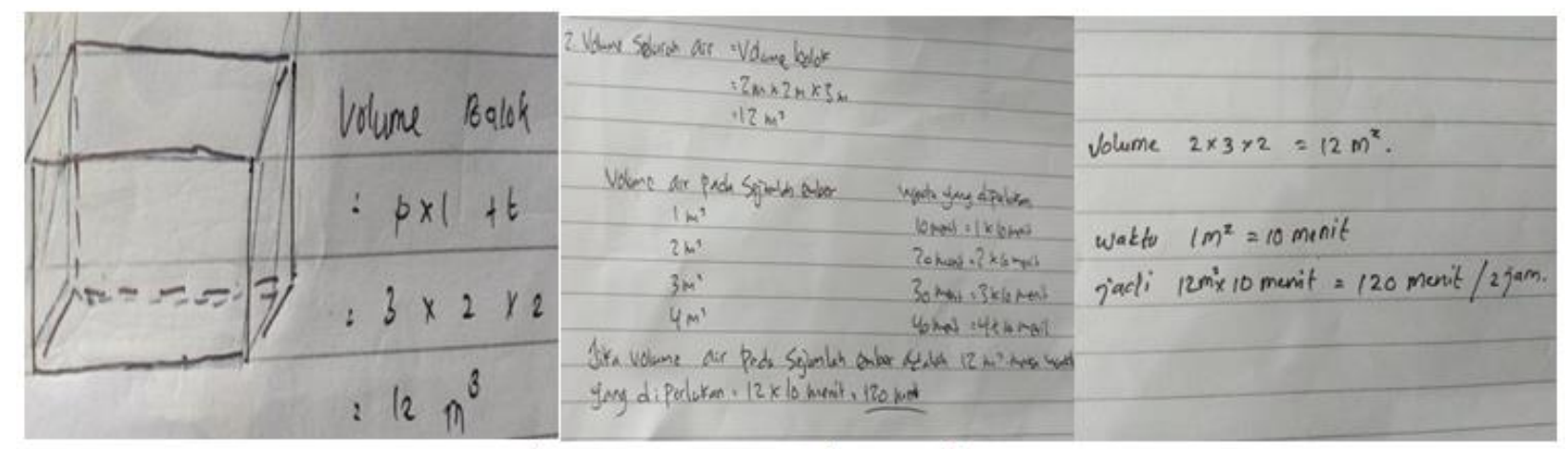

Figure. 4. Errors students on issues 2.

Figures 3 and 4 are some examples of the answers is done by male and female student. Based on Figure 3, students can present a statement according to the indicators into one picture but not complete because of things that are known and asked not written so that the second indicator is filed conjecture also not been met. Otherwhise with other indicators, the students are still difficulties in manipulating mathematical and give evidence against create dan solution that most students do not give any conclusions based on the answer to the first problem.

In Figure 4, the majority of the results of the students' answers correct, but some indicators in the reasoning put forward have not been met. Based on Figure 4, the students are still not able to present a picture into the appropriate indicator statement 1 . The solution provided is correct, but when asked about the solutions the students are still hesitant so that students are still wrong in checking the validity of the argument advanced in the solution. As in the first issue above most of the students did not provide conclusions based on the answers to these two problems. The results in Figure 3 and 4 reinforces the data in Figure 2 above that the mistakes made by students men and women do almost all indicators of reasoning set. The dominant error is on the indicator 3rd, 4th, and 5th.

\section{Discussion}

The results showed that the students made some mistakes on every indicator of reasoning. The dominant error is on the indicator $3^{\text {rd }}, 4^{\text {th }}$, and $5^{\text {th }}$ that perform mathematical manipulations and provide a reason or evidence to the truth of the solution, check the validity of an argument and draw conclusions. This supports previous research that there were 6 types of errors based on five types of Newman procedural errors and one type of error resulting from students' carelessness [16].

In the first problem, errors in the first and second indicators namely presenting statements mathematics through writing, drawing, sketching or diagrams and submitting conjectures (conjecture) will result in errors in the next indicator. Students cannot change statements in problems to drawings or symbols. Students have problems communicating given problems and students have problems communicating mathematical problems in the form of written text [17]. 
This makes students fail to remember the concepts used in solving problems [15]. The first step that must be done is internal structuring by identifying mathematical objects only consist of basic problems to get the characteristics of the problem [18].

Lack of understanding of the basic concepts of a topic results in failure to use formal procedures to solve several types of problems [19]. In the second problem, most students answered correctly, but some students answered not using the reasoning procedure [20]. The results showed that male students made more mistakes than female students. This result is different from the results of previous studies that male students excel in science and reasoning [12]. This is based on differences in the underlying information processing reasoning strategy models are used and generalized to emotional processing [12]. Female students get better results on verbal reasoning tests, while male students are slightly superior in quantitative reasoning tests [20]. To find out more about other factors that influence these differences, it must be explored further about the different ways of reasoning male and female students.

\section{Conclusion}

The results of this study indicate that female student have reasoning ability better than male student. Another finding that students can make mistakes in every stage of reasoning is based on five indicators of reasoning that researchers ask. These results provide further benefits to explore how to think of students who make mistakes in every indicator reasoning primarily on third indicator it is perform mathematical manipulations and give reasons or proof of the authenticity of the solution and fourth indicator it is checking the validity of an argument, and fifth indicator it is conclusions. The results of this study can also be used by teachers as a basis for preparing the teaching materials as well as in the teaching process and pay attention so that the error of reasoning that the students can be minimized.

The researcher suggests that based on the results of this study, it is found that students can make mistakes in reasoning and female students have better reasoning than male students. This case provides an opportunity to do more research about how the process of error in reasoning is based on gender.

\section{References}

[1] NCTM, Curriculum and Evaluation Standards for School Mathematics, (VA. Reston, National Council of Teachers of Mathematics, 2000).

[2] J. Litner, "Mathematical Reasoning in task Solving," in Educational Studies in Mathematics, (2000), pp.165-190.

[3] D.H. Scunk, Learning Theories, (Pearson, Boston, 2012) 
[4] Akinmola, "Developing Mathematical Problem Solving Ability: A Panacea For A Sustainable Development In The 21st Century," in International Journal of Education and Research, (2014), pp.1-8.

[5] K. Kristayulita et al, J. Phys.: Conf. Ser. 1028012154 (2018).

[6] B. Kramarski., \& Z.R. Mevarech, "Enhancing the Mathematical Reasoning in the Classroom: The Effects of Cooperative Learning and metacognitive Training," in American Educational Research Journal, (2003),pp. 281-310.

[7] B.A. Adegoke, "Modelling the Relationship between Mathematical Reasoning Ability and Mathematics Attainment," in Journal of Education and Practice, (2013),pp.54-61.

[8] A. Setiawan, "Hubungan Kausal Penalaran Matematis terhadap Prestasi Belajar Matematika pada Materi Bangun Ruang Sisi Datar ditinjau dari Motivasi Belajar Matematika Siswa,” Al -Jabar: Jurnal Pendidikan Matematika, (2016),pp. 91-100.

[9] R. Choudhury \& D.K. Das, "Influence of geometrical ability and study habit on the achievement in mathematics at secondary stage", International Journal of Computational Engineering Research, (2012), pp.232 - 236.

[10] Heng-Yuku \& H.G. Sullivan, "Personalisation of mathematics word problems in Taiwan," in Educational Technology Research and Development, (2000),pp. 49 -59.

[11] T. Nunes., P. Byrant., R. Barros \& K. Sylva, "The relative importance of two different mathematical abilities to mathematical achievement," in British Journal of Journal of Educational Psychology, (2012),pp.136-156.

[12] H. Markovits., B. Trémolière., \& I. Blanchette, "Reasoning strategies modulate gender ff erences in emotion processing," in Cognition, (2018), 76-82.

[13] J. Kuhn \& H. Holling, "Gender, reasoning ability, and scholastic achievement: A multilevel analysis mediation," in Learning and Individual Differences,(2009),pp. 229-233.

[14] F. Arwadi, “The Influence Of Mathematical's Reasoning Ability And Gender Difference Towards Mathematical Conceptual Understanding," In Proceedings of ICMSTEA: International Conference on Mathematics, Science, Technology, Education, and their Applications, (2016), 355-361.

[15] L.E.S. Moguel., E.P. Landa \& G. Cabañas-Sánchez, "Characterization of Inductive Reasoning in Middle School Mathematics Teachers in a generalization Task," in International Electronic Journal Of Mathematics Education, (2019), pp. 563-581.

[16] K. Saleh., I. Yuwono., A.R. As'ari, \& C. Sa'dijah, "Errors analysis solving problems analogies by Newman procedure using analogical reasoning," in International Journal of Humanities and Social Sciences, (2017),pp.17-26.

[17] Sumaji et al, IOP Conf. Ser.: Earth Environ. Sci. 243012128 (2019). 
[18] S. Lailiyah et al, IOP Conf. Ser.: Mater. Sci. Eng. 296012029 (2018).

[19] S. Strand., I. Deary \& P. Smith, Sex differences in cognitive abilities test scores: A UK national picture," in British Journal of Educational Psychology, (2016),pp. 463-480.

[20] L.J. Nyaumwe, Math. Educ.11 (2) 181-96 (2008).

[21] H. Hendriana., E.E. Rohaeti \& U. Sumarmo, "Hard Skills dan Soft Skills Matematik Siswa" (Refika Aditama, Bandung, 2017).

[22] Depdiknas, “Peraturan Dirjen Dikdasmen No. 506/C/PP/2004, (Depdiknas, Jakarta, 2004). 